
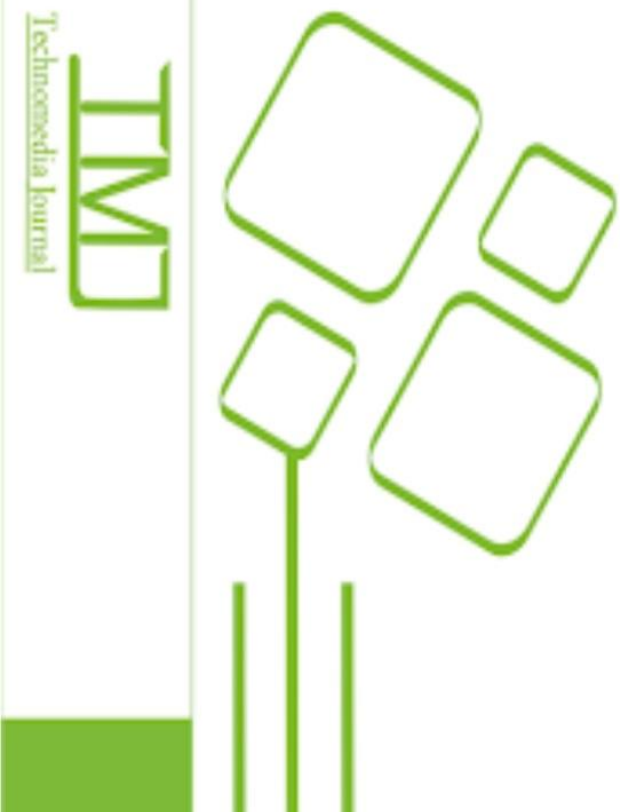

E-ISSN: 2528 - 6544

P-ISSN: 2620 - 3383

Vol.1 No.1 Agustus 2016

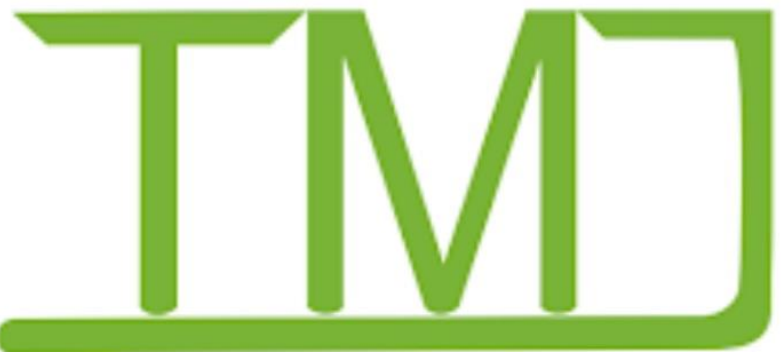

Technomedia Journal

iLearning Journal Center (iJC)

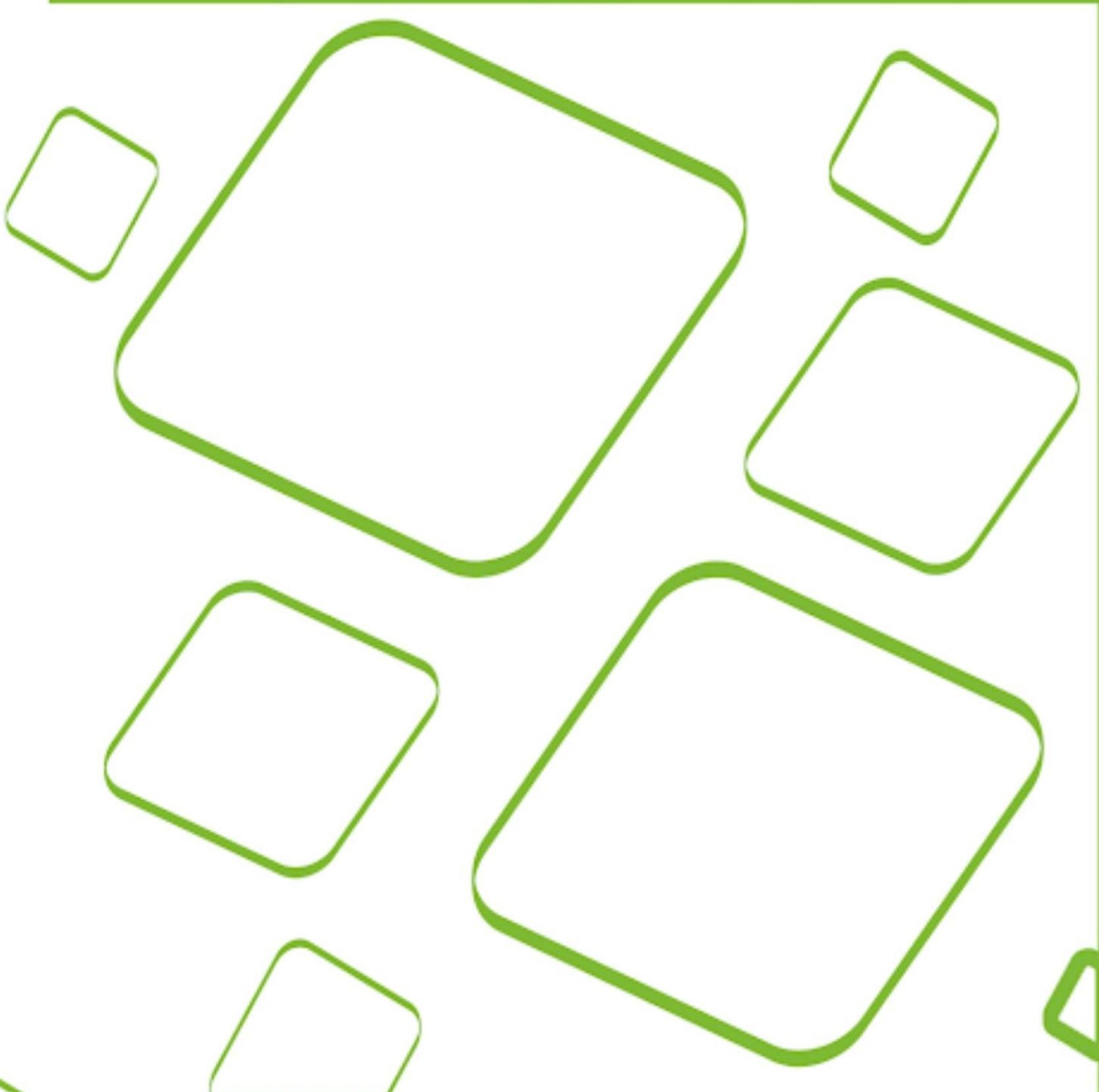


Technomedia Journal adalah jurnal elektronik ilmiah yang diterbitkan oleh iJC (iLearning Journal Center). Technomedia Journal terbit tiga kali dalam satu tahun Februari, Juni, dan Oktober yang berisi artikel hasil penelitian dalam bidang Sistem Informasi dan Teknologi Informatika.

\section{Ketua Redaksi :}

Ir. Untung Rahardja.,M.T.I

Sekretaris Redaksi :

Indri Handayani, S.Kom., M.T.I

Mitra Bestari :

Prof. Ir. Joko Lianto Buliali, M.Sc.,Ph.D

Prof. Dr.rer.nat. Achmad Benny Mutiara, SSi, SKom

Prof. Dr. Moedjiono. MSc

Dr. Winarno

Dr. Harco Lesly

Panca Oktavia Hadi Putra, Bsc., M.Sc.,

Henderi, M.Kom

Dr. Ir. I. Joko Dewanto, MM

Dr. Ir. Sudatyono, S.Pd., M.Pd

\section{Editor/ Layout : \\ Maulana Sani \\ Yuli Widiastuti}

\section{Bendahara:}

Eka Purnama Harahap, S.Kom

\section{Alamat Redaksi :}

Jl. Jendral Sudirman No 40, Cikokol - Tangerang Tel / fax : (021)5529692

Email: ijc@ raharjagroups.info atau ijc@ raharja.info 


\section{Dewan Redaksi}

Puji dan syukur kehadirat Allah SWT atas karunia dan lindunganNya sehingga TMJ terbitan Vulume 1 Nomor 1 Edisi Oktober 2016 dapat diterbitkan tepat waktu.

Penerbitan jurnal ini dimaksudkan sebagai media informasi ilmiah dibidang ilmu komputer yang diharapkan dapat membantu para dosen dan mahasiswa dalam menginformasikan hasil penelitian dan kajian ilmiah lainnya kepada berbagai komunitas ilmiah diseluruh Indonesia.

Penerbitan jurnal Volume 1 Nomor 1 Edisi Oktober 2016 berisikan 10 artikel yang mencakup bidang Ilmu Komputer, Teknologi Informasi, Sistem Informasi, walaupun tidak seluruhnya merupakan hasil penelitian diharapkan dapat bermanfaat bagi pembacanya. Puji syukur kehadirat Allah SWT karena 10 artikel adalah dari STMIK dan AMIK Raharja.

Jurnal ini diterbitkan dengan memuat artikel Fitur Form Emailer Dalam Memaksimalkan Penggunaan Rinfo Form Pada Perguruan Tinggi, Implementasi Fgr (First Generation Resources) Dengan Menggunakan Mailchimp Sebagai Sarana Informasi Di Perguruan Tinggi, Optimalisasi Penerapan Rooster Berbasis Osticket Untuk Meningkatkan Mutu Pelayanan, Penerapan Rinfosheet Sebagai Media Penunjang Pembuatan Laporan Untuk Mahasiswa, Penerapan Rinfosheet Sebagai Media Penunjang Pembuatan Laporan Untuk Mahasiswa, Optimalisasi Viewboard Rhjfox Berbasis Bootstrap Sebagai Sistem Penunjang Keputusan, Penerapan Viewboard Go+ Berbasis Yii Sebagai Media Monitoring Pembayaran Mahasiswa, Pemanfaatan Rinfo Form Sebagai Media Pembuatan Kuesioner Dalam Proses Pengumpulan Data Pada Perguruan Tinggi, Pemanfaatan Google Scholar Dan Citation Dalam Memenuhi Kebutuhan Pembuatan Skripsi Mahasiswa Pada Perguruan Tinggi, Penerapan Mata Uang Armo (Airzone-Mall Money) Pada Marketplace Airzone-Mall Sebagai Inovasi Pembelajaran Internet Dan E-Commerce, Media Audio Visual Menggunakan Videoscribe Sebagai Penyajian Informasi Pembelajaran Pada Kelas Sistem Operasi.

Tidak lupa pula pada kesempatan ini kami mengundang para pembaca untuk mengirimkan naskah hasil penelitian kepada kami. Dan tidak lupa pula kami mengucapkan banyak terimakasih kepada semua pihak yang telah membantu penerbitan jurnal ini.

Tangerang, 31 Oktober 2016

Redaksi 


\section{Daftar Isi}

1. FITUR FORM EMAILER DALAM MEMAKSIMALKAN PENGGUNAAN RINFO FORM PADA PERGURUAN

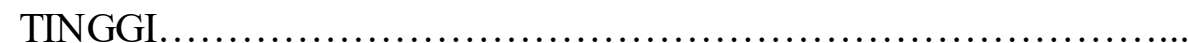
Indri Handayani, Qurotul Aini, Reza Alfiansah

2. IMPLEMENTASI FGR (FIRST GENERATION RESOURCES) DENGAN MENGGUNAKAN MAILCHIMP SEBAGAI SARANA INFORMASI DI PERGURUAN TINGGI Qurotul Aini, Indri Handayani, Nuril Huda

3. OPTIMALISASI PENERAPAN ROOSTER BERBASIS OSTICKET UNTUK MENINGKATKAN MUTU PELAYANAN. Untung Rahardja, Khanna Tiara, Ria Utami

4. PENERAPAN RINFOSHEET SEBAGAI MEDIA PENUNJANG PEMBUATAN LAPORAN UNTUK MAHASISWA ... Khanna Tiara, Erlita Rasdiana, Nursam Somantri

5. OPTIMALISASI VIEWBOARD RHJFOX BERBASIS BOOTSTRAP SEBAGAI SISTEM PENUNJANG KEPUTUSAN...... Untung Rahardja, Khanna Tiara, Maya Ima Erviani

6. PENERAPAN VIEWBOARD GO+ BERBASIS YII SEBAGAI MEDIA MONITORING PEMBAYARAN MAHASISWA .............. $\quad$ 65-77 Khanna Tiara, Tuti Nurhaeni, Ika amalia

7. PEMANFAATAN RINFO FORM SEBAGAI MEDIA PEMBUATAN KUESIONER DALAM PROSES PENGUMPULAN DATA PADA PERGURUAN TINGGI.... Erlita Rasdiana, Fadil Nur Muhamad, Ridwan Kurniaji

8. PEMANFAATAN GOOGLE SCHOLAR DAN CITATION DALAM MEMENUHI KEBUTUHAN PEMBUATAN SKRIPSI MAHASISWA PADA PERGURUAN TINGGI....................... Untung Rahardja, Khanna Tiara, Iis Ariska Rosalinda

9. PENERAPAN MATA UANG ARMO (AIRZONE-MALL MONEY) PADA MARKETPLACE AIRZONE-MALL SEBAGAI INOVASI PEMBELAJARAN INTERNET DAN E-COMMERCE. Qurotul Aini, Untung Rahardja, Dita Lintang Nurani

10. MEDIA AUDIO VISUAL MENGGUNAKAN VIDEOSCRIBE SEBAGAI PENYAJIAN INFORMASI PEMBELAJARAN PADA KELAS SISTEM OPERASI. 


\title{
Pemanfaatan Rinfo Form Sebagai Media Pembuatan Kuesioner Dalam Proses Pengumpulan Data Pada Perguruan Tinggi
}

\author{
Erlita Rasdiana S.Kom ${ }^{1}$ \\ Fadil Nur Muhamad ${ }^{2}$ \\ Ridwan Kurniaji ${ }^{3}$ \\ Jl. Jendral Sudirman No. 40, Modernland, Tangerang ${ }^{1,2,3}$ \\ Email: erlita@ raharja.info ${ }^{1}$,fdolimanhum@gmail.com ${ }^{2}$, ridwan@raharja.info $^{3}$
}

\begin{abstract}
ABSTRAK
Pengumpulan data dengan menggunakan kuesioner jika dilakukan dengan cara yang konvensional akan memerlukan banyak kertas dan memerlukan biaya lebih untuk memperoleh data. Saat ini mayoritas pengguna gadget pasti memiliki email, di karnakan email adalah salah satu media yang paling aman dan sangat mudah untuk saling bertukar file data maupun hal yang lain, dan semestinya pula kita harus memaksimalkan penggunaan fasilitas yang sudah ada tersebut yakni salah satunya adalah GOOGLE DOC. Google doc. adalah salah satu fasilitas dari gmail.com. Kali ini penulis akan memperkenalkan salah satu fasilitas dari google doc tersebut yaitu Google Form, google form ini memiliki banyak fungsi di antaranya untuk membuat formulir pendaftaran, kemudian untuk membuat daftar ceklis, membuat daftar daftar lain yang caranya dengan meminta seseorang untuk mengisi daftar pertanyaan yang telah di buat sesusai keperluan. Form yang telah dibuat nantinya akan di share, sehingga akan ada beberapa orang yang bersangkutan setuju dan dapat mengisi beberapa pertanyaan yang kita buat pada google form tersebut, selain dengan cara di share formulir ini juga dapat langsung dikirimkan via email, ketika sudah ada orang yang mengisi form yang telah dibuat maka data harus tersebut dikirim kembali sehingga akan menghasilkan data jawaban dari pertanyaan yang telah yang diajukan, sehingga dapat digunakan sebagai acuan untuk kegiatan yang diselenggarakan. formulir lewat internet ini adalah aspek yang sangat membantu sekali untuk mempermudah pengumpulan data. Google Form telah di gunakan oleh Tim OJRS+ dalam pengumpulan data tingkat kepuasan mahasiswa dalam penggunaan sistem informasi OJRS+ Diharapkan penggunaan Google Form ini dapat memudahkan dalam pengumpulan data terutama dari segi keakuratan data serta mengurangi penggunaan kertas pada perguruan tinggi.
\end{abstract}

Kata kunci: Googleform, kuesioner, perguruan tinggi

\begin{abstract}
Collecting data using questionnaires if done in a conventional manner will require a lot of paper and cost more to acquire the data. Currently the majority of users of the gadget definitely has email, in karnakan email is one of the media's most secure and very easy to exchange data files or anything else, and should also we have to maximize the use of existing facilities such that one of them is GOOGLE DOC, Google doc. is one of the perks of gmail.com. This time the author will introduce a facility of google doc that is Google Form, google this form has many functions in between to make the registration form, and then to make a list of the checklist, make a list of other lists that way by
\end{abstract}

78 | Erlita, Fadil, Ridwan-Pemanfaatan Rinfo Form Sebagai... 
asking someone to fill out a questionnaire which has been made sesusai purposes. Forms that have been made will be shared, so there will be some people concerned agree and can fill some of the questions that we create on google the form, other than by way shared this form can also be sent directly via email, when already there are people who fill form that has been made then the data must be sent back so that it will generate data answers to questions that have been raised, so that it can be used as a reference for the activities organized. form over the internet this is an aspect that is very helpful to facilitate the collection of data. Google Form has been in use by Team OJRS + in the data collection level of student satisfaction in the use of information systems OJRS + It is hoped that the use of this Google Form can facilitate the collection of data, especially in terms of data accuracy and reduce the use of paper in college.

Keywords: Googleform, questionnaire, college

\section{PENDAHULUAN}

Kemajuan pada bidang dan teknologi informasi yang semakin meningkat seiring dengan perkembangan zaman yang mampu memenuhi berbagai macam data terutama kebutuhan dan informasi dari pengguna. Kebutuhan akan kecepatan dan keamanan dalam penyampaian informasi dan akses data pun semakin canggih dan menjadi salah satu media pendukung hampir diseluruh aspek kehidupan salah satu contohnya dibidang pendidikan yaitu pada perguruan tinggi, dimana setiap perguruan tinggi selalu meningkatkan mutu dan kualitasnya dengan cara mengembangkan fasilitas yang tersedia pada perguruan tinggi tersebut, sarana dan prasarana yang dapat digunakan secara maksima oleh mahasiswa.

Perguruan Tinggi Raharja merupakan salah satu institusi pendidikan yang bergerak di bidang teknologi informasi. Oleh karena itu, Perguruan Tinggi Raharja terus menerus melakukan peningkatan dan pengembangan, baik berupa sistem pembelajaran kampus ataupun sistem pelayanan yang ada pada Perguruan Tinggi Raharja.

Rinfo Form yang telah di gunakan di perguruan tinggi raharja merupakan salah satu fasilitas dari Google Form. jadi Rinfo Form adalah Google Form hanya di perguruan tinggi raharja menyebutnya sebagai Rinfo Form untuk ciri khas, Rinfo Form yang di manfaatkan oleh mahasiswa untuk membuat kuesioner untuk pengumpulan sekitar 4500 data (data pada http://ojrsplus.raharja.ac.id) untuk kepentingan TA maupun SKRIPSI untuk menggunakan Google Form mahasiswa, di wajibkan memiliki alamat Email yang aktif untuk login kedalam Google Drive untuk selanjutnya dapat menggunakan Google Form untuk membuat kuesioner untuk pengumpulan data. Dengan demikian OJRS sangat berperan penting dalam perkembangan kualitas sistem pelayanan kampus khususnya bagi mahasiswa.

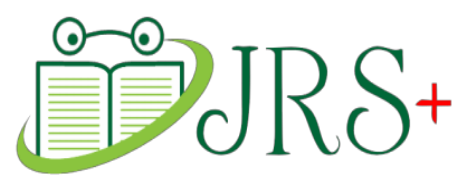

Sumber : Filosofi Logo OJRS+ Gambar 1. TampilanLogo OJRS+ 


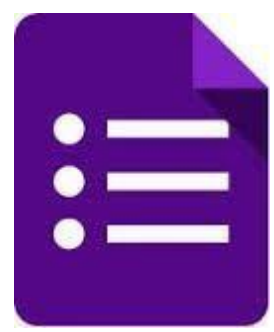

Sumber : Rinfo Form

Gambar 2. Logo Google Form

Sebagai bentuk pemanfaatan fasilitas yang diberikan Google Doc, Perguruan Tinggi Raharja memanfaatkan fasilitas tersebut untuk membuat kuesioner untuk di berikan kepada mahasiswa untuk kepentingan pengumpulan data di perguruan tinggi.

Sebagai salah satu lembaga pendidikan yang bergerak dibidang IT (Information Technology), Perguruan Tinggi Raharja terus-menerus melakukan inovasi demi membuat suatu media dan sistem informasi untuk di gunakan dalam kebutuhan sehari-hari. untuk itu dalam metode pembelajaran juga harus mengalami evolusi kearah yang lebih modern dan canggih, dan tidak harus dibuat secara konvensional akan tetapi telah berbasis kepada teknologi informasi. Perguruan Tinggi Raharja mempunyai visi yaitu meningkatkan kualitas pendidikan untuk menciptakan SDM yang bermutu. Dalam rangka mencapai visi tersebut, Perguruan Tinggi Raharja selalua berusaha mewujudkan visinya dalam bentuk pengadaan program-program studi yang menunjang pengembangan dan penerapan Teknologi Informasi dalam berbagai bidang.

\section{PERMASALAHAN}

Dalam proses pembuatan form kuesioner yang berjalan pada Perguruan Tinggi Raharja masih dilakukan dengan cara konvensional, dapat dilihat dari 2 segi permasalahan yakni dari segi mahasiswa, dosen dan Tim OJRS+.

Dari segi mahasiswa, permasalahan yang sering terjadi jika masih menggunakan cara konvensional adalah terganggunya proses belajar saat di bagikannya form kuesioner, terkadang ada mahasiswa yang lupa membawa alat tulis dan jika mahasiswa tersebut ingin meminjam ke teman satu kelasnya akan membuat suasana kelas bising dan tidak kondusif . jika mahasiswa tidak bisa mengikuti perkuliahan di pastikan tidak dapat ikut serta mengisi kuesioner karena lebar kuesioner hanya dapat di bagikan di kelas saja, dan mengurangi jumlah data yang di dapat dan mengurangi tingkat ke efektifan kesioner itu sendiri.

Dari segi dosen, permasalahan yang sering terjadi adalah jika pengumpulan data melalui kuesioner ingin di lakukan, dosen harus mengambil kertas tersebut dan membawanya ke ruangan, hal itu cukup merepotkan terlebih lagi jika ruangan mengajarnya berada di lantai atas tentu saja hal tersebut sangat memakan waktu dan tenanga, dan saat mahasiswa selesai mengisi kuesioner dosen harus membawa kembali kertas kuesioner tersebut untuk di kumpulkan untuk melakukan perhitungan. Dan yang pasti kegiatan pengumpulan data menggunakan metode konvensional sangat boros kertas dan akan memakan biaya yang cukup besar. Dan jika pengumpulan data tersebut di lakukan dengan cara konvensional saat perhitungan / rekapitulasi pasti akan memakan waktu yang lama, berbeda jika sudah 
menggunakan Google Form. Dari segi Tim OJRS+ permasalahan yang terjadi kepada Tim OJRS+ jika pengumpulan data menggunakan kuesioner dengan cara konvensional yang pertama adalah boros kertas, yang otomatis memerlukan biaya dalam pembuatan kuesioner itu sendiri, dan harus menyiapkan print out untuk di bagikan kepada seluruh dosen pengajar yang nantiya akan di bagian di kelas.

Dari permasalahan tersebut di atas dapat disimpulkan secara detail berdasarakan penjabaran tentang sistem pendukung yang tergambar dalam mind mapping di bawah ini :

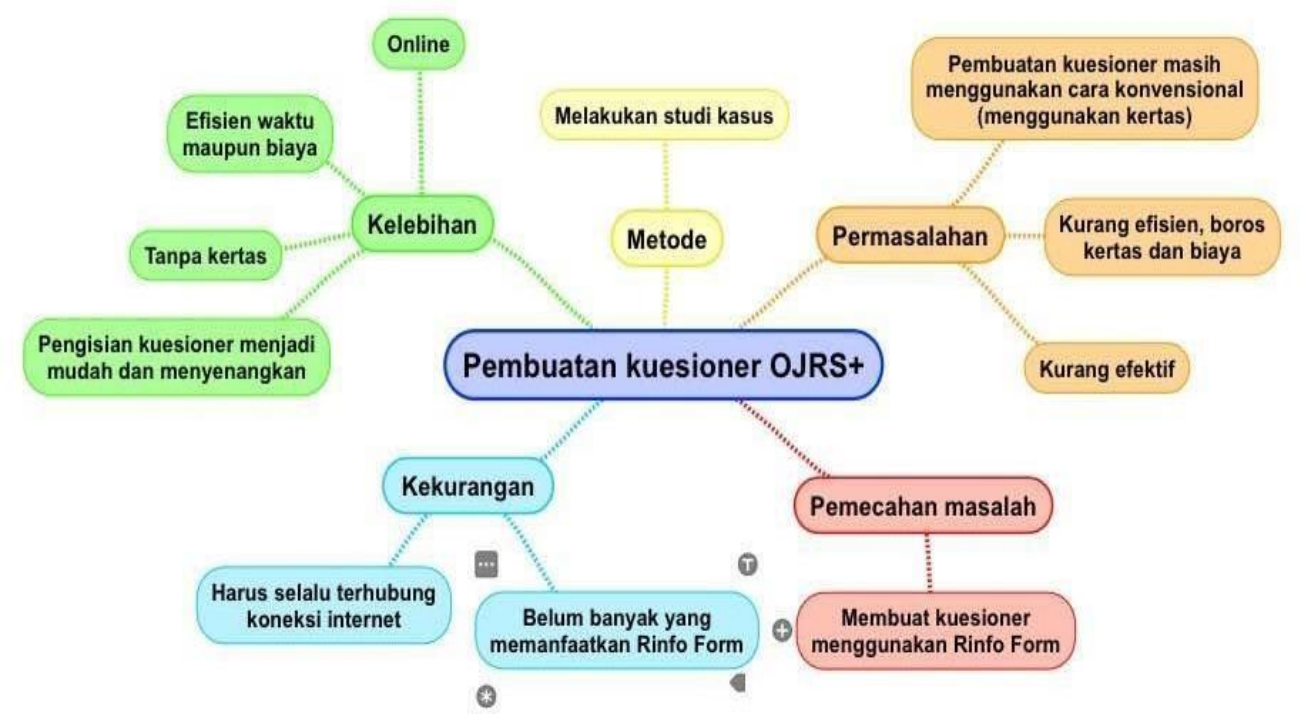

Sumber : Mindmapping

Gambar 3. Mind Mapping pengisian kuesioner OJRS+

Berdasarkan gambar mindmap di atas proses pengumpulan data survey menggunakan kuesioner yang kemudian akan diberi solusi untuk pemecahan masalah dengan menggunakan metode yang terkait. Dan pembuatan minmap ini bertujuan untuk memudahkan dalam melakukan analisa.

Dalam melakukan penelitian yang membahas tentang pemanfaatan google form ini, metode yang di gunakan adalah studi kasus yang dilakukan pada perguruan tinggi sebagai lingkup penelitian ini. Tujuan penelitian studi kasus khusus menjelaskan dan memahami obyek yang diteliti secara khusus sebagai sebuah kasus. Adapun tujuan yang berkaitan dengan hal tersebut, bahwa tujuan penggunaan penelitian studi kasus ini adalah tidak hanya untuk menjelaskan untuk apa obyek tersebut di teliti, akan tetapi bertujuan untuk mendeskripsikan bagaimana keberadaan masalah tersebut dan mengapa masalah tersebut dapat terjadi di perguruan tinggi raharja. 


\section{SWOT}

\begin{tabular}{|c|c|c|}
\hline $\begin{array}{l}\text { Analisis } \\
\text { Permasalahan dengan } \\
\text { metode SWOT }\end{array}$ & $\begin{array}{l}\text { Kekuatan (Strength) } \\
\text { 1. Berbasis Online. } \\
\text { 2. Mudah Di } \\
\text { dukumentasikan. } \\
\text { 3. Paperless. } \\
\text { 4. Data Lebih Akurat } \\
\text { 5. Mudah Dalam } \\
\text { Pengisian Kuesioner. }\end{array}$ & $\begin{array}{l}\text { Kelemahan (Weakness) } \\
\text { 1. Harus terkoneksi } \\
\text { internet. } \\
\text { 2. Harus memiliki Rinfo } \\
\text { 3. Terkadang responden } \\
\text { kurnag obyektif }\end{array}$ \\
\hline $\begin{array}{l}\text { Peluang (Oportunity) } \\
\text { 1. } \begin{array}{l}\text { Dapat } \\
\text { mempermudah } \\
\text { dalam penghitugan }\end{array} \\
\text { jumlah responden. } \\
\text { 2. } \begin{array}{l}\text { Menghemat biaya } \\
\text { operasinal }\end{array}\end{array}$ & $\begin{array}{l}\text { Strategi SO } \\
\text { 1. Hasil responden dapat } \\
\text { di bagi berdsasarkan } \\
\text { jenis kelamin } \\
\text { 2. Share Form Survey } \\
\text { menggunakan media } \\
\text { Gmail. }\end{array}$ & 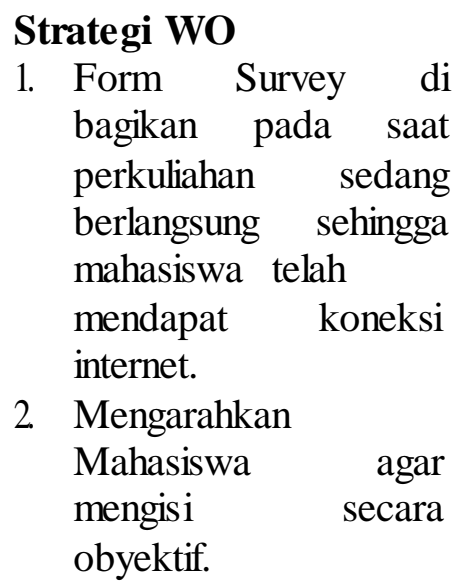 \\
\hline $\begin{array}{l}\text { Ancaman (Thread) } \\
\text { 1. Jumlah Responden } \\
\text { tidak tetap } \\
\text { 2. Jika mengalami } \\
\text { Request Time Out } \\
\text { maka form tidak } \\
\text { dapat di isi. }\end{array}$ & $\begin{array}{l}\text { Strategi ST } \\
\text { 1. Mendata mahasiswa } \\
\text { yang tidak hadir pada } \\
\text { perkuliahan dan } \\
\text { mengirimkan Survey } \\
\text { melalui Email }\end{array}$ & $\begin{array}{l}\text { Strategi WT } \\
\text { 1. Memberi arahan } \\
\text { kepada mahasiswa } \\
\text { untuk menunggu } \\
\text { selagi koneksi } \\
\text { terputus suapaya form } \\
\text { dapat di isi kembali. }\end{array}$ \\
\hline
\end{tabular}

\section{LITERATURE REVIEW}

Literature review adalah bahan yang tertulis berupa buku, jurnal yang membahas tentang topik yang hendak diteliti ([Menurut Hermawan 2009:45]). Dalam upaya menerapkan Rinfo Form sebagai media dalam pembuatan kuesioner untuk survey dan pengumpulan data, oleh sebab itu tentunya sudah banyak sekali penelitian yang mengkaji perihal ini, di bawah ada beberapa diantaranya adalah sebagai berikut :

Penelitian Penelitian yang dilakukan oleh Untung Rahardja, Khanna Tiara, dan Ray Indra pada tahun 2014 dengan judul -Penerapan Rinfo Sebagai Media Pendukung Untuk Proses Pembelajaran Pada Perguruan Ti nggi Raharjall menjelaskan bahwa penerapan 
Rinfo sebagai media komunikai sekaligus alat pendukung dalam proses pembelajaran secara online di Perguruan Tinggi Raharja. Rinfo adalah Gmail yang diadaptasi dari Google Platform, karena berasal dari Google Platform maka Rinfo terhubung pula dengan alat penunjang pembelajaran lainnya, seperti Docs, Drive, Sites, dan alat penunjang lainnya.

2. Penelitian yang dilakukan oleh Andi Susilo dan Yasmiati, mengenai Google Apps Untuk Proses Pembelajaran di Fakultas Teknologi Informasi, Universitas Respati Indonesia. Meneliti tentang migrasi email dan pengimplementasiaan Google Apps for Education untuk memperbaiki proses pembelajaran melalui metode blended learning di Fakultas Teknologi Informasi, Universitas Respati Indonesia. Pembelajaran tersebut sudah berbasis cloud computing dengan layanan yang telah diaktifkan meliputi Gmail, Google Sites, Google Docs, Gtalk, Google Calendar, Google Groups, Postini Services, dan Google Contacts dengan subdomain fti.urindo.ac.id. Penerapan Google Apps for Education dilakukan di seluruh komponen kampus dan diharapkan akan mengurangi biaya secara signifikan terhadap investasi software dan hardware yang ada di Universitas Respati Indonesia, khususnya di Fakultas Teknologi Informasi.

Penelitian yang dilakukan oleh Wiranto Herry Utomo pada tahun 2015 dengan judul -Analisis perbandingan Cloud DOCUMENT pada EYeOS dan Google docsl. Penelitian ini bertujuan menganalisis perbandingan antara eyeOS dengan Google Docs sebagai alternatif yang lebih baik yang harus digunakan untuk membantu pengguna dalam masalah pendokumntasian. Dokumen berupa dokumen pengolah kata, spreadsheet, dan presentation. Perbandingan antara eyeOS dengan Google Docs ini nantinya akan diketahui manakah yang paling efektif serta efisien yang dibutuhkan untuk keperluan dokumentasi dan dokumen dapat dibagikan ke para user lainnya.

4 Penelitian yang dilakukan oleh Ana Rusmardiana pada tahun 2015 dengan judul -KAJIAN PENERIMAAN TEKNOLOGI CLOUD COMPUTING GOOGLE DRIVE DALAM SISTEM PEMBELAJARAN SISWA TINGKAT SMK\|. Salah satu teknologi baru yang mengalami perkembangan pesat teknologi komputasi awan (cloud storage). SMK di Jakarta adalah sebuah sekolah kejuruan yang mempromosikan pengembangan dan penggunaan teknologi informasi untuk kegiatan belajar mengajar siswa. Oleh karena itu, sekolah merasa perlu untuk memperkenalkan media penyimpanan dan berbagi data pada siswa bahwa tidak ada hambatan untuk penyelesaian tugas, yaitu aplikasi Google Drive. Model yang digunakan dari Technology Acceptance Model (TAM) untuk menyertakan dua variabel eksternal, yaitu CSE dan TT dan 4 variabel menerima adalah PEOU, PU, ATT dan IU untuk mengetahui aplikasi Google Drive penerimaan teknologi. Beberapa faktor yang dapat mempengaruhi atau moderasi di antara jenis kelamin / seks dan Status Sekolah. Pengambilan sampel menggunakan kuesioner dengan 180 responden 
di 20 SMK di jakarta. Metode pengolahan data menggunakan Structural Equation Model (SEM) dengan menggunakan AMOS 18.0 software.

j Penelitian yang dilakukan oleh Qurrotin A'yunina pada tahun 2015 dengan judul -PENGARUH PENERAPAN SISTEM INFORMASI DATABASE RISET DAN PENGABDIAN MASYARAKAT (SIDR) DI LINGKUNGAN UNIVERSITAS

INDONESIAl. Sistem Informasi Database Riset dan Pengabdian Masyarakat (SIDR) merupakan suatu sistem informasi yang digunakan untuk menyimpan data riset dan pengabdian mayarakat di lingkungan Universitas Indonesia. Untuk mengevaluasi keefektifan SIDR, perlu dilakukan pengambilan data tentang respon pengguna SIDR terhadap teknologi sistem informasi ini. Sehingga dalam studi ini, metode kuisioner dengan 6 poin skala Likert diterapkan untuk mendapatkan informasi tersebut. Secara umum, hasil penelitian menunjukkan bahwa SIDR memberikan kemudahan dalam pembuatan laporan hasil riset serta terpusatnya data-data hasil riset dan pengabdian masyarakat untuk seluruh fakultas di Universitas Indonesia.

6 Penelitian yang dilakukan oleh Isti Pujihastuti pada tahun 2010 dengan judul -PRINSIP PENULISAN KUESIONER PENELITIANII. Penelitian ilmiah berusaha memberikan simpulan dan saran yang realistis, hal ini dapat diperoleh apabila proses penelitiannyapun menggunakan prinsip penelitian ilmiah. Salah satu faktor yang cukup menentukan keberhasilannya terkait dengan data yang dikumpulkan. Terdapat berbagai metode pengumpulan data pada penelitian ilmiah, misalnya observasi, eksperimen, survei, analisis isi (content analysis) dan wawancara.

Penelitian yang dilakukan oleh Andri Heryandi pada tahun 2012 dengan judul -PEMBANGUNAN SISTEM INFORMASI PENGISIAN SURVEY EVALUASI PERKULIAHAN ONLINE DI UNIVERSITAS KOMPUTER INDONESIAl.

Penjaminan mutu merupakan suatu hal yang penting dilakukan pada suatu perguruan tinggi. Universitas Komputer Indonesia (UNIKOM) telah beberapa tahun melakukan proses penjaminan mutu yang salah satunya menggunakan instrument berupa kuesioner. Kuesioner ini digunakan untuk mengevaluasi proses perkuliahan yang telah berlangsung. Setiap mahasiswa mengisi kuesioner berdasarkan matakuliah-matakuliah yang diambil ketika perwalian. Data kuesioner yang telah diisi mahasiswa kemudian dapat diakses melalui Sistem Informasi Evaluasi Perkuliahan (SIMEP).

8 Penelitian yang di lakukan oleh Hyunyoung Choi pada tahun 2012 dengan judul -Predicting the Present with Google Trends| Dalam tulisan ini kita menunjukkan bagaimana menggunakan data mesin pencari untuk meramalkan nilai jangka dekat indikator ekonomi. Contohnya termasuk mobil penjualan, klaim pengangguran, perencanaan tujuan wisata dan kepercayaan konsumen. 
9 Penelitian yang di lakukan oleh Hangwi Tang Pada Tahun 2006 dengan judul -Googling for a diagnosis - use of Google as a diagnostic aid: internet based studyll tentang Tujuan Untuk menentukan seberapa sering mencari dengan Google (mesin pencari paling populer di dunia web yang luas) mengarah dokter untuk diagnosis yang benar. studyusing berdasarkan desain internet Google untuk mencari diagnosis; peneliti buta terhadap diagnosis yang benar.

1 Penelitian yang di lakukan oleh Michael Rowe, Vivienne Bozalek dan Jose Frantz pada tahun 2013 dengan judul -Using Google Drive to facilitate a blended approach to authentic learning\| yang mengkaji tentang Google Drive digunakan sebagai lingkungan authoring secara online kolaboratif di mana kelompok-kelompok kecil siswa yang digunakan kasus klinis untuk membuat konten mereka sendiri, dipandu oleh tim fasilitator. Makalah ini menjelaskan pendekatan inovatif untuk pendidikan klinis menggunakan pembelajaran otentik sebagai kerangka membimbing, dan Google Drive sebagai platform implementasi. Kami percaya bahwa pendekatan ini menyebabkan transformasi praktek belajar siswa, hubungan kekuasaan diubah di dalam kelas dan memfasilitasi pengembangan sikap kritis terhadap pengetahuan dan otoritas.

Dari 10 (sepuluh) literature review diatas, sebagian besar adalah membahas perihal pemanfaatan fasilitas google drive, google doc dan google form. Berdasarkan dari literature review yang telah di buat dua diantaranya membahas tentang aplikasi dengan platform google yang berfungsi sebagai media pendukung ke dalam proses pembelajaran, dan salah satunya adalah Rinfo. Hal ini berkaitan dengan penelitian yang dilakukan, akan tetapi untuk penelitian yang sudah ada sebelumnya mengkaji secara luas fungsi dari Rinfo, belum secara total membahas secara khusus fasilitas yang terdapat pada Rinfo terutama RinfoDocs. Dapat disimpulkan bahwa belum ada penelitian yang membahas tentang -Pemanfaatan Rinfo Form Sebagai Media Pemubatan Kuesioner Dalam Proses Pengumpulan Data Terhadap Sistem Informasi OJRS+ Pada Perguruan Tinggi.l.

\section{PEMECAHAN MASALAH}

Untuk mengatasi masalah yang ada, diperlukan suatu cara baru pembuatan kuesioner untuk keperluan pengumpulan data. Rinfo Form bisa dijadikan sebagai solusi yang tepat untuk mengatasi masalah-masalah yang telah diuraikan diatas. Rinfo Form adalah salah satu fasilitas dari RinfoDrive yang di berikan oleh Rinfo, sedangkan Rinfo itu sendiri adalah sebuah layanan email yang di berikan husus oleh Perguruan Tinggi Raharja sebagai magic key untuk Pribadi Raharja .

Bagi setiap Pribadi Raharja harus mempunyai Email Rinfo, di karenakan hampir seluruh proses pembelajaran pada Perguruan Tinggi Raharja membutuhkan Rinfo sebagai media pendukung untuk kelancaran proses belajar mengajar. Bila ada mahasiswa yang belum memiliki Rinfo di pastikan akan sulit mengikuti pelajaran terutama bagi mahasiswa iLearning 
karena hampir semua kegiatan belajar harus login menggunakan Rinfo, tidak hanya untuk pendukung proses belajar mengajar, Rinfo juga dibutuhkan untuk login ke situs-situs penting untuk mengatur KST dan mengambil form-form untuk keperluan kuliah. Mahasiswa yang memiliki email Rinfo dapat langsung memanfaatkan fasilitas Rinfo Forim yang telah tersedia dan siap di gunakan untuk berbagai keperluan.

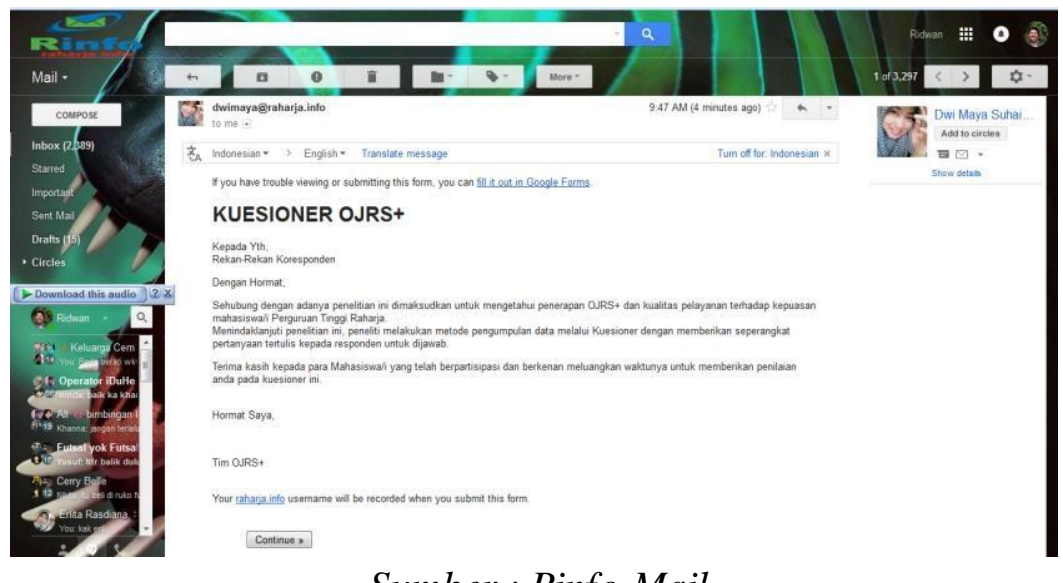

Sumber : Rinfo Mail

Gambar 4. Email dari Tim OJRS+ Untuk mengisi Kuesioner OJRS+

Gambar 5. Merupakan gambar kuesioner OJRS+, gambar ini berisi 30 pertanyaan, petunjuk cara pengisian dan kriteria penilaian. Kuesioner ini akan diberikan kepada mahasiswa Perguruan Tinggi Rahaja sebagai responden. Cara seperti ini lebih efektif dari pada harus print kuesioner, hemat kertas dan hemat biaya. Oleh karena itu pemanfaatan fasilitas Rinfo Form ini.

Demi mempermudah penjabaran dari penerapan Rinfo Form, maka akan digunakan cara alternatif penggambaran sistem melalui alur flowchart. Di bawah ini merupakan alur dalam penggunaan Rinfo Form yang akan digambarkan dengan Usecase Diagram dan Flowchart, mulai dari LoginRinfo, Membuat Kuesioner di Google Form, Share Kuesioner, dan Mendapatkan jawaban dari responden. 


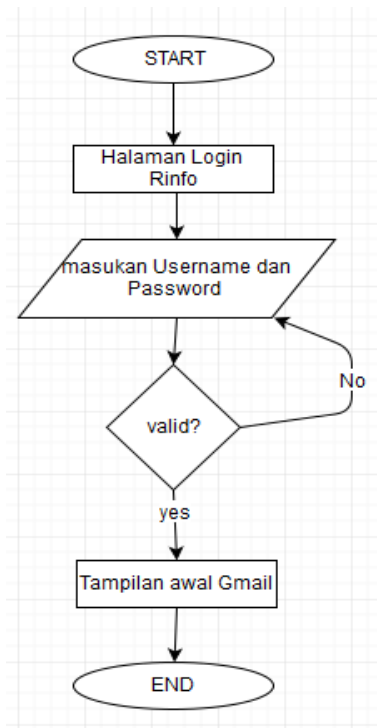

Sumber : Draw.io

\section{Gambar 5. Flowchart Rinfo}

Dari Flowchart diatas menjelaskan proses login ke email Rinfo. Pertama-tama mahasiswa harus mengunjungi halaman http:/gmail.com. Setelah itu input username dan password. setelah username dan password yang di input valid, maka mahasiswa berhasil masuk ke halaman Rinfo, akan tetapi jika username dan password salah maka user masih tetap berada dihalaman yang sama dan disarankan untuk mengulang memasukkan akun (username dan password) yang valid.

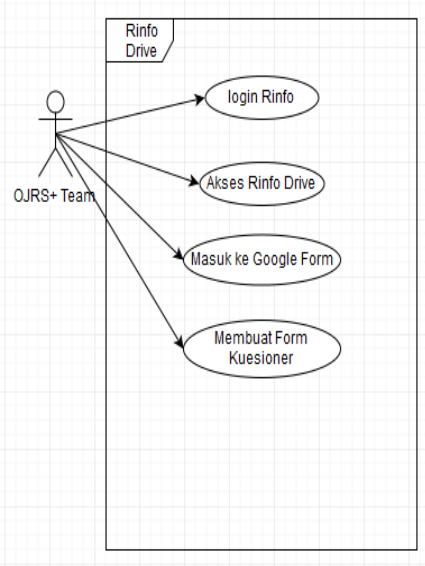

Sumber : Draw.io

Gambar 6. Usecase Diagram pembuatan Rinfo Form

Usecase Diagram di atas menjelaskan tentang proses pembuatan kuesioner. pertamatama harus melakukan Login Rinfo di halaman https//drive.google.com/. Jika sudah bisa login ke email Rinfo, maka mahasiswa dapat langsung menggunakan fasilitas Rinfo Form pada Rinfo Drive lalu dapat langsung membuat kuesioner. 


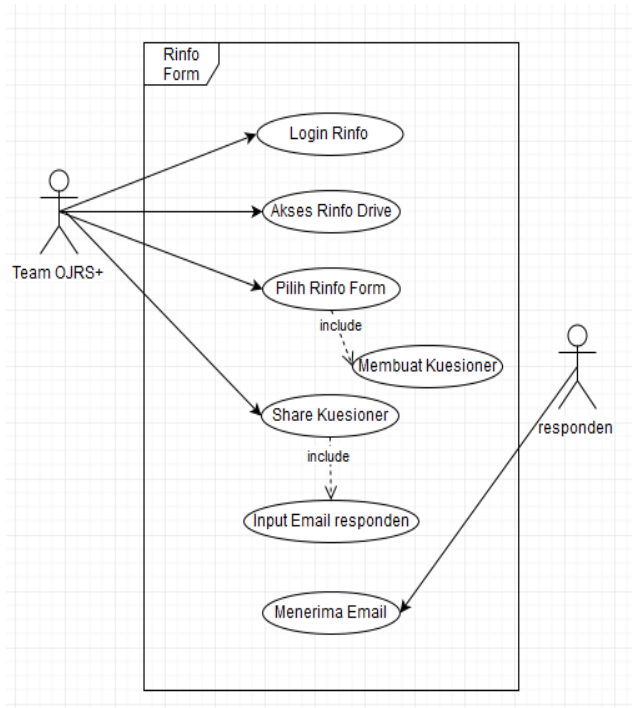

Sumber: Draw.io

Gambar 7. Usecase Diagram Share kuesioner

Usecase diagram diatas menjelaskan proses share kuesioner pada Rinfo Form yang dilakukan oleh Team OJRS+. Pertama Team OJRS+ harus login rinfo selanjutnya akses Rinfo Drive untuk masuk ke tampilan Google Form jika sudah, share kuesioner yang telah di buat dan input seluruh Email responden. Selanjutnya responden akan menerima Email notifikasi dan langsung dapat menjawab pertanyaan yang ada di kuesioner tersebut.

\section{LISTING PROGRAM}

Pada rinfo ini merupakan fasilitas dari GoogleDrive dengan menggunakan bahasa program CSS. Berikut merupakan kodingannya : 


\begin{tabular}{|c|c|}
\hline 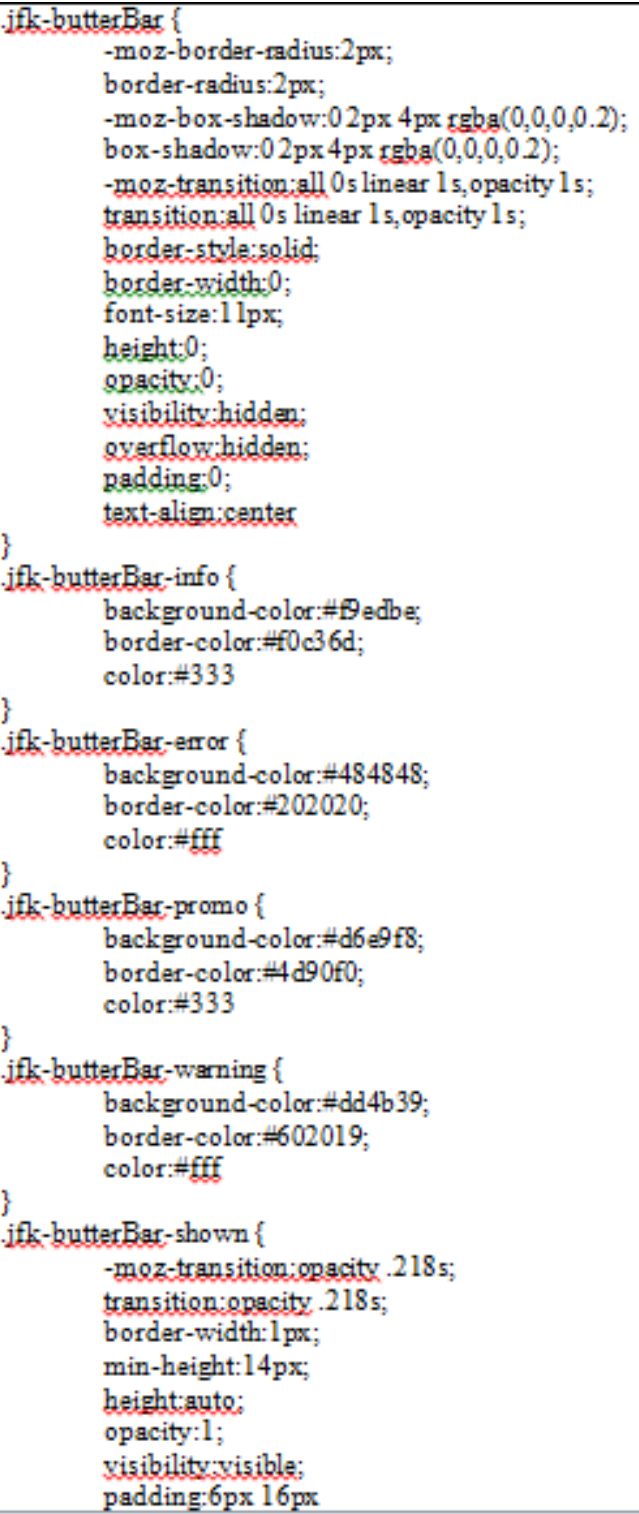 & 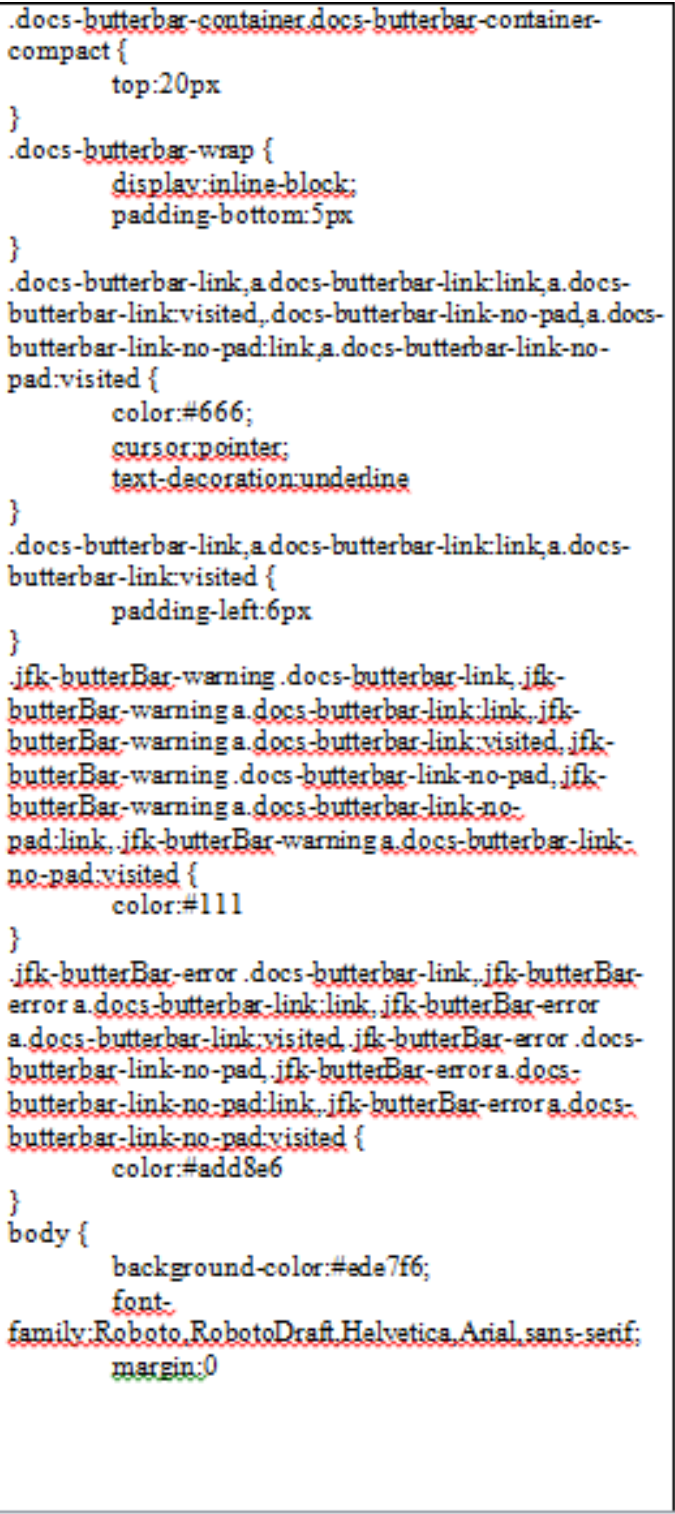 \\
\hline
\end{tabular}

\section{IMPLEMENTASI}

\section{Halaman Login Rinfo Drive}

Implementasi adalah pelaksanaan serangkaian kegiatan dalam rangka untuk memberikan kebijakan publik sehingga kebijakan dapat membawa hasil([syaukani 2004 : 295]) Pada halaman Login Rinfo ada dua form isian yaitu username dan password email Rinfo. Untuk dapat mengakses email Rinfo, seluruh Pribadi Raharja harus mengisi form Emailnya terlebih dahulu untuk dapat mengakses Rinfo Drive. Halaman Login Rinfo ini dapat diakses pada http://drive.google.com/. 


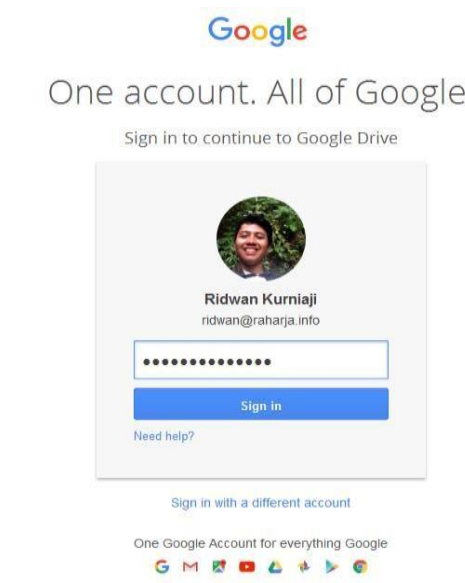

Sumber: Rinfo Drive

Gambar 8. Login Rinfo Drive

2. Tampilan Rinfo Drive

Mahasiswa yang telah berhasil LoginRinfo, akan langsung masuk ke halaman utama Rinfo Drive. Di dalam tampilan Rinfo Drive ini ada beberapa menu di antaranya untuk Membuat dokumen baru, Shared With me, Google Photo, Recent dan lain sebagainya.

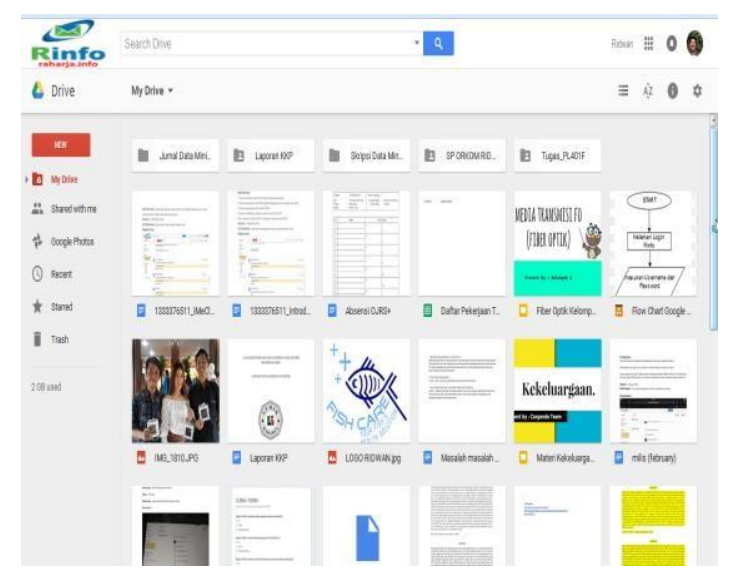

Gambar 9. Tampilan Rinfo Drive

\section{Tampilan Rinfo Form}

Pada tampilan halaman Rinfo Form sangat mudah untuk di pahami. Seluruh tools untuk keperluan edit radio button, warna form dan menduplicate pertanyaan yang di buat jadi lebih mudah. Karena fasilitas Rinfo Form ini berbasi Online, mahasiswa harus selalu terkoneksi internet. 


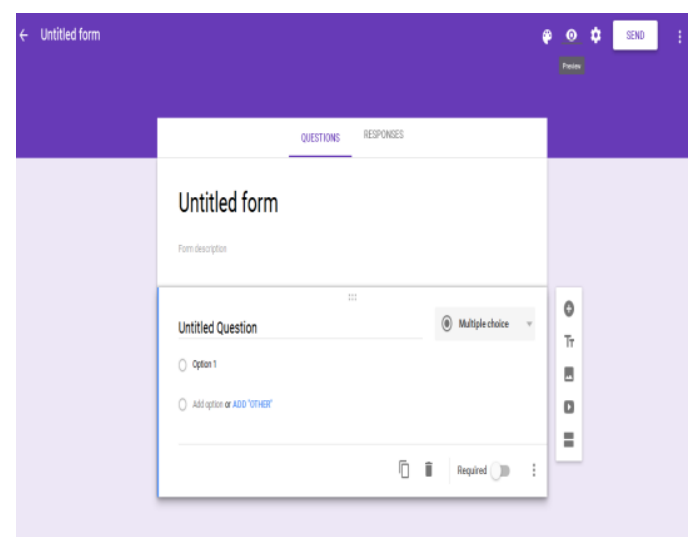

Gambar 10. Tampilan Rinfo Form

\section{Tampilan Send/Share Rinfo Form}

Pada tampilan share laporan di Rinfo Form terdapat beberapa form isian yang digunakan untuk memasukkan daftar responden yang di perkenankan untuk mengisi kuesioner tersebut, selanjurnya ada form subject, fungsinya untuk memberi judul email kita supaya lebih mudah di kenali dan selanjutnya message fungsinya untuk memberikan deksripsi kuesioner yang telah kita share supaya mahasiswa mudah memahami maksud dari pengisian kuesioner tersebut.

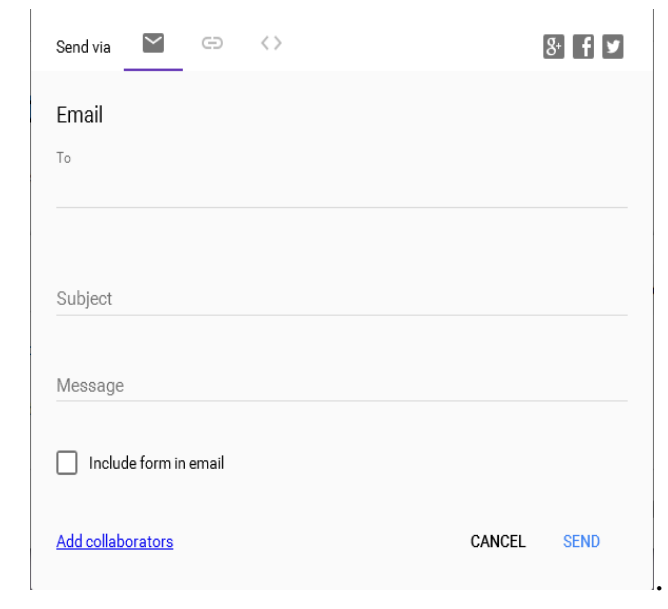

Gambar 11. Tampilan Share/Send Kuesioner

\section{Tampilan Email Dari Tim OJRS+}

Setelah Tim OJRS+ mengirim kuesioner kepada mahasiswa, mahasiswa akan merima tampilan seperti pada Gambar 12. Tampilan Rinfo Mahasiswa mahasiswa akaan menerima email permintaan untuk mengisi kursioner, dan cara mengisinya hanya tinggal mengklik buttom Continue dan tampilan kuesioner OJRS+ akan muncul. 


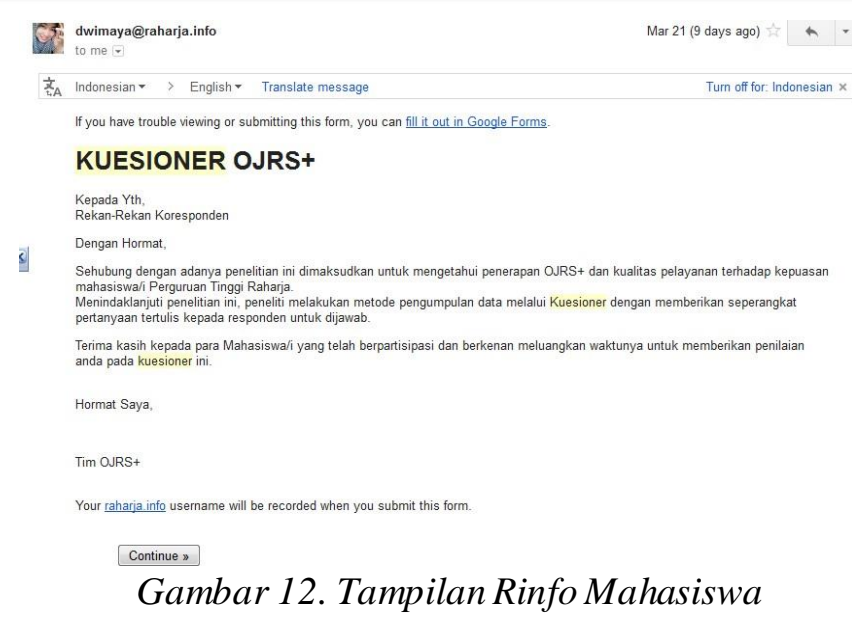

\section{Tampilan Awal Kuesioner OJRS+}

Karena kuesioner yang di buat menggunakan Rinfo Form berbasis online, mahasiswa maupun dosen tidak perlu mengeluarkan kertas dalam pengumpulan data. Mahasiswa hanya perlu memilih option yang sudah di sediakan.

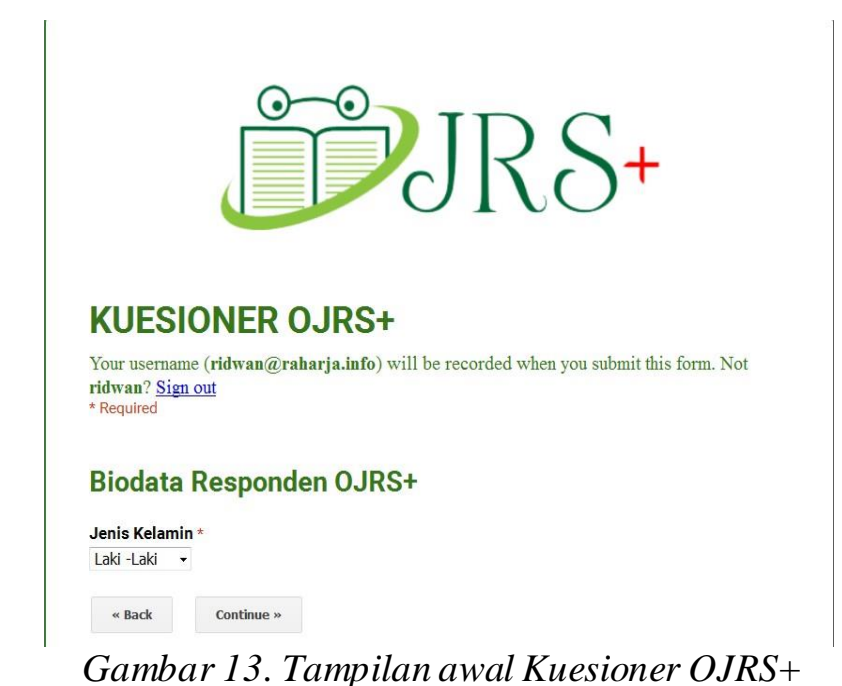

7. Tampilan Isi Kuesioner OJRS+

Pada tampilan isi kuesioner OJRS+ terdapat beberapa pertanyaan yang bertujuan mengumpulkan penilaian atau pendapat responden terhadap sistem Informasi OJRS+. 


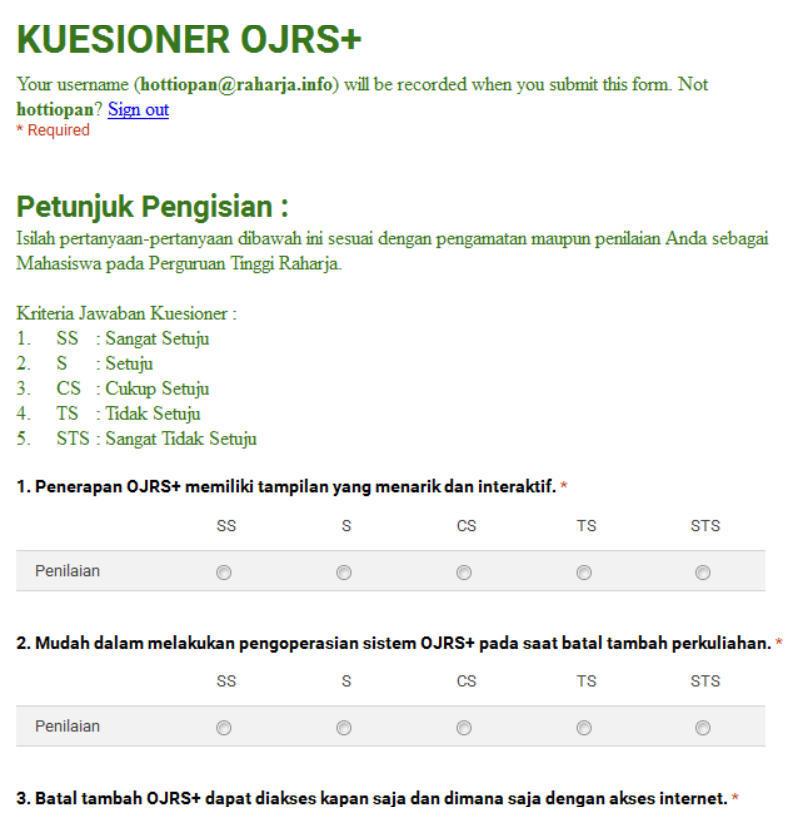

Gambar 14. Tampilan isi Kuesioner OJRS+

\section{Tampilan Responden Kuesioner}

Setelah responden mengisi kuesioner maka grafik yang ada pada google form akan menggambarkan tentang banyaknya mahasiswa yang mengisi kuesioner berdasarkan jenis kelamin.

\section{7 responses}

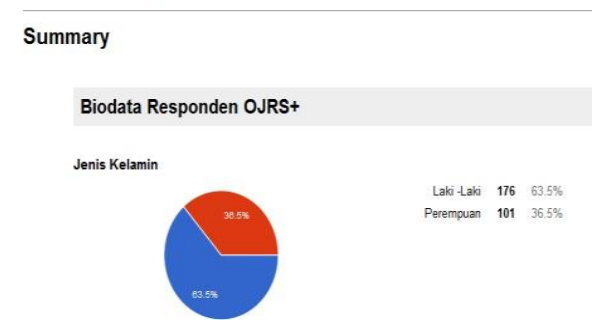

Gambar 15. Pengumpulan data / rekapitulasi menggunakan Google Form

\section{KESIMPULAN}

Kesimpulan dari penelitian ini yaitu fasilitas dari RinfoDrive yang diberikan oleh Rinfo, lalu Rinfo melainkan sebuah fasilitas Gmail yang menggunakan platform Google yang sudah di berikan secara khusus oleh pihak Perguruan Tinggi Raharja yang di tujukan untuk Pribadi Raharja. Dikarenakan melalui platform email Google, dari Rinfo memberikan fasilitas penunjang dalam pembuatan kuesioner Rinfo Form, GoogleDrive untuk menyimpan kuesioner dan berbagai data. Rinfo Form berhasil memecahkan masalah akibat pembuatan kuesioner dengan cara konvensional yaitu menggunakan kertas, Rinfo Form sangat membantu karena dapat di oprasikan secara online dan pastinya jauh dari penggunaan kertas. Begitu juga data yang di dapat juga lebih akurat,Di samping mudah dalam pengoprasian, 
Rinfo Form lebih hemat biaya karena tidak menggunakan kertas. mudah dalam proses rekapitulasi dan terdokumentasi dengan baik. Adanya fasilitas yang di berikan oleh Google diharapkan dapat di manfaatkan dengan baik oleh seluruh perguruan tinggi.

\section{DAFTAR PUSTAKA}

II. Rahardja, Untung, Khanna Tiara, dan Ray Indra Taufik Wijaya. 2014. -Penerapan Rinfo Sebagai Media Pendukung Untuk Proses Pembelajaran Pada Perguruan Tinggi Raharjall. Jurnal CCIT Vol.8 No.1 September 2014. ISSN: 1978 - 8282. Tangerang : Perguruan Tinggi Raharja.

月) Susilo, Andi. Yasmiati. -Google Apps Untuk Proses Pembelajaran di Fakultas Teknologi Informasi (FTI), Universitas Respati Indonesia-. ISSN: 1907-5022.

8] Herry Utomo, Wiranto 2015. "Analisis perbandingan Cloud DOCUMENT pada EYeOS dan Google docs”. Department of Computer System Engineering Diponegoro University - Indonesia, Vol 5, No 1

\#) Rusmarina, Ana. 2011. : -Kajian Penerimaan Teknologi Cloud Computing Google Drive Dalam Sistem Pembelajaran Siswa Tingkat SMK\|. Teknik Informatika Universitas Indraprasta PGRI Jakarta, Vol 3, No 1.

ॠ] A'yunina, Qurrotin. 2015. -Pengaruh Penerapan Sistem Informasi Database Riset Dan Pengabdian Masyarakat (SIDR) Di Lingkungan Universitas Indonesia.\|. Fakultas Ilmu Komputer, Universitas Indonesia, Vol 11, No 1.

6] Pujihastuti Isti. 2010. -Prinsip Penulisan Kuesioner Penelitian.l. Jurnal Agribisnis dan Pengembangan Wilayah. Vol 2, No 1

7] Heryandi Andri. 2012. -Pembangunan Sistem Informasi Pengisian Survey Evaluasi Perkuliahan Online Di Universitas Komputer Indonesia.\|. Jl. Dipati Ukur 112 - 116 Bandung, Vol. 1 No. 2.

8] Choi, Hyunyoung. 2012 "Predicting the Present with Google Trends" The Economic Record, VOL. 88, Special Issue, JUNE, 2012, 2-9

9] Tang, Hangwi. 2006 -Googling for a diagnosis - use of Google as a diagnostic aid: internet based study\| BMJ VOL 333. 2 December 2006

Ill Rowe., Michael, Vivienne Bozalek dan Jose Frantz. 2013 "Using Google Drive to facilitate a blended approach to authentic learning" British Journal of Educational Technology. Volume 44, Issue 4, pages 594-606, July 2013

[II] Hermawan. 2009. "Penelitian Bisnis". Jakarta: Grasindo.

[1. Syaukani, H, dkk. 2004. Otonomi Derah dalam Negara Kesatuan. Yogyakarta:Pustaka Pelajar. 